$5-28-2021$

\title{
Arts \& Literature: Feeding Her Child a Green Slipper Instead of a Cucumber
}

Kaziwa Salih

Queen's University, Canada

Follow this and additional works at: https://digitalcommons.usf.edu/gsp

\section{Recommended Citation}

Salih, Kaziwa (2021) "Arts \& Literature: Feeding Her Child a Green Slipper Instead of a Cucumber," Genocide Studies and Prevention: An International Journal: Vol. 15: Iss. 1: 13-21.

DOI:

https://doi.org/10.5038/1911-9933.15.1.1827

Available at: https://digitalcommons.usf.edu/gsp/vol15/iss1/5

This Arts \& Literature is brought to you for free and open access by the Open Access Journals at Digital Commons @ University of South Florida. It has been accepted for inclusion in Genocide Studies and Prevention: An International Journal by an authorized editor of Digital Commons @ University of South Florida. For more information, please contact digitalcommons@usf.edu. 


\section{Arts \& Literature: Feeding Her Child a Green Slipper Instead of a Cucumber}

\section{Acknowledgements}

My gratitude to Margo Kelly who gave some feedback on the short version of this piece. 


\title{
Arts \& Literature: Feeding Her Child a Green Slipper Instead of a Cucumber
}

\author{
Kaziwa Salih \\ Queen's University \\ Kingston, Ontario, Canada
}

\begin{abstract}
About the Art Work
This essay is a personal story of one of the Kurdish Anfal genocide survivors named Nabat Fayiaq Rahman. During her research fieldwork in 2017, the author interviewed Nabat in BaniGul, which is a village in Chamchamal district in the Kurdistan region. Nabat's story is the result of the Anfal genocide that took place in Iraq and lasted between 1986 and 1989.
\end{abstract}

\begin{abstract}
About the Author
Kaziwa Salih has a Ph.D. in Cultural Studies from Queen's University in Canada, with a focus on cultural sociology of genocidal violence against the Kurds in Iraq. She is the award-winning author of several fiction and non-fiction books. Salih was a founder and the editor-in-chief of two journals, Nivar and Newkar. Her research interests include Cultural Studies, CulturalSociology and Cultural-Psychology of violence, Migration and Displacement, Kurdish Studies, Middle East Politics, and Women Identity, Ethnic Conflicts, State, and Non-State Actors, and Yazidi Affairs.
\end{abstract}




\title{
Feeding Her Child a Green Slipper Instead of a Cucumber
}

I first observed the confident, sad, yet hopeful face of Nabat Fayiaq Rahman through the black screen of the TV. She was wearing a traditional black Kurdish outfit that matched the stage curtains designed for the anniversary of the Anfal genocide, marked on April 14 of every year. The Kurdish Anfal genocide in Iraq was perpetrated by Saddam Hussein's regime in the 1980s. Human Rights Watch (1994) estimates that 182,000 Kurds were buried alive in mass graves, many of which were found after Hussein was overthrown. More than 2.5 million people were displaced, 4500 villages destroyed, and 250 towns and villages exposed to chemical weapons.

Nabat was from one of the destroyed villages, in a district called Qadir Karam in the Kirkuk province. Her red eyes, which indicated she'd been crying throughout the event, did not match her angry voice. "What did the government do for us?" she asked. "They did nothing. Once a year, during the anniversary, they [the government] remember that the Anfal genocide happened."

Nabat's voice disappeared into a chorus of female voices sorrowfully singing a heartening lullaby, which until that moment had been meekly in the background of the program.

\author{
Lullaby, lullaby, lullaby. \\ The grief of the Kurds makes me lose my voice \\ To sing lullaby for all of you, each one thrice \\ Lullaby for my burning soul that doesn't rest day or night \\ Lullaby for my sons \\ Lullaby for my daughters \\ Lullaby for my husband, who was a leading Knight \\ Lullaby for my parents \\ Lullaby for my sisters \\ Lullaby for my brother, who was my posh \\ Lullaby for neighbours who turned to ash \\ Sleep, my loved ones \\ You may find peace in the grave \\ Since the Earth is a slaughtering cave
}

The lullaby is a prominent piece of art in Kurdish society, and the only method through which the female survivors of the Kurdish genocides can express their anguish since they don't have access to psychiatric treatment. However, I am against treating the Kurdish genocides with only lullabies and speeches. The Kurdish genocides require serious attention that should go beyond singing lullabies and expressing emotions.

The lullaby multiplied in my ear. I don't know if it was the lyric, or if my mind made up its own lullaby because I'd been hearing them ever since I was a child. Historically, Kurdish culture is known for many different types of lullabies: to send children to sleep, to mend lovers' broken hearts, to record oral history, to pass on classic stories of wisdom. But it has been a century since the lullaby turned mainly into a dark lullaby of the dead, especially during the anniversary of the Kurdish genocides. 
I wrote Nabat's full name down and the name of the region where she lived, making a promise that I'll go all the way to Kurdistan, if only to see her.

The women who survived the Kurdish Anfal genocide are mostly isolated, and clad in black outfits, both of which have been part of the villagers' culture for over thirty years. Among them, a few elderly survivors attend the genocide events mostly to perform lullabies and make audiences weep. Nabat's presence on TV was impressive. In the culturally conservative and male-dominated society of the villages, survivors have chosen silence over speech, and some of them refuse to tell their stories, even anonymously, all due to cultural and psychological burdens.

Unlike Nabat, I've wiped away my tears, and managed to fake a smile while reminding myself that here is an illiterate widow, a single mother of several children, victimized by one of the most violent events in history, not only telling her story but also participating in a conference on the Kurdish genocide in Iraq, criticizing and fighting the government about the rights of the Anfal genocide survivors.

By the summer of 2017, I was in Kurdistan, at Nabat's home in BaniGull village. Habil Ahmad, a General Manager of the Directorate of Anfal Monument in Chamchamal, arranged for me to meet her and had helped me with transportation.

When we met, as expected, Nabat was fully clad in a traditional black outfit. She had been donning it since 1988 in her untraditional way of attempting to make a difference. This time, her red eyes and hopeless face expressed the unspeakable agonies of a heartbroken woman and a mother of seven children who felt that no one understood her pain. My sister Nyan, who accompanied me on this trip, took a few photos of her.

It is challenging to ask victims to relive the trauma they experienced. After I expressed this concern, Nabat replied, "I want to tell not only the Kurds, but the entire world what happened to us; and yet the problems we suffered during the Anfal cannot be put into words."

Even so, she thought it worth trying, and recounted how she was captured in April 1988, along with her husband, seven children (four sons and three daughters), four brothers-in-law, and several cousins. The people of her village, she continued, were taken to concentration camps in the south of Iraq.

Nabat was released after six months, "by a miracle," as she calls it, but she lost two of her children in those camps: a seven-year-old son and a three-year-old daughter.

What was the cause of their deaths?

"Hunger and disease," she said. "We were put in a huge barn filled with animal excrement and cockroaches. The barn was full of women and children with no food or drink. Once a day, we received a piece of bread with a glass of water."

She choked on her tears. Her eyes were fixed on an abstract point faraway, and her arms were locked across her chest while she moved her head back and forth. This went on for a while until her gaze moved to the clock, and suddenly, as if she'd remembered something important, she called out a female name. It was 12.20 p.m. 
A beautiful teenage girl, presumably Nabat's daughter, entered the room. After greeting me, she asked her mother if she needed anything. Nabat asked her to prepare lunch for me.

As a member of the community, I already knew about Kurdish etiquette and hospitality: It was expected that I should eat in their home. But I didn't want to be a burden so I quickly said that I preferred a light meal; perhaps a tomato and cucumber salad, I added.

Silence ensued, and my thoughts wandered to the injustice Nabat had encountered. Despite her anguish, she looked like she couldn't be older than fifty. If thirty years ago as she said, she was a mother of seven children, it meant she had got married when she was still a child. Yes, I thought, she was one of the many whose childhood had been stolen from her. When she should have been enjoying the beauty of youth, she was forced to be a mother, a wife, and later had to carry the pain of genocide; of losing her loved ones; of being a widow, alone, and having to look after five children in a male-dominated society.

I didn't bother confirming her age. "In the end, it's not the years in your life that count; it's the life in your years," said Abraham Lincoln.

Between Nabat and me, where we were seated, stood was a traditional ivory Kurdish pillow with brown flowers and sage leaves. Lost in our silence, I watched her, while she made repeated movements with her index finger, as if pushing the fallen leaf toward the twig of the flower. She was remapping her lost world, I thought. How I wish we could rejoin the broken branch to the family tree just by the art of finger-pointing.

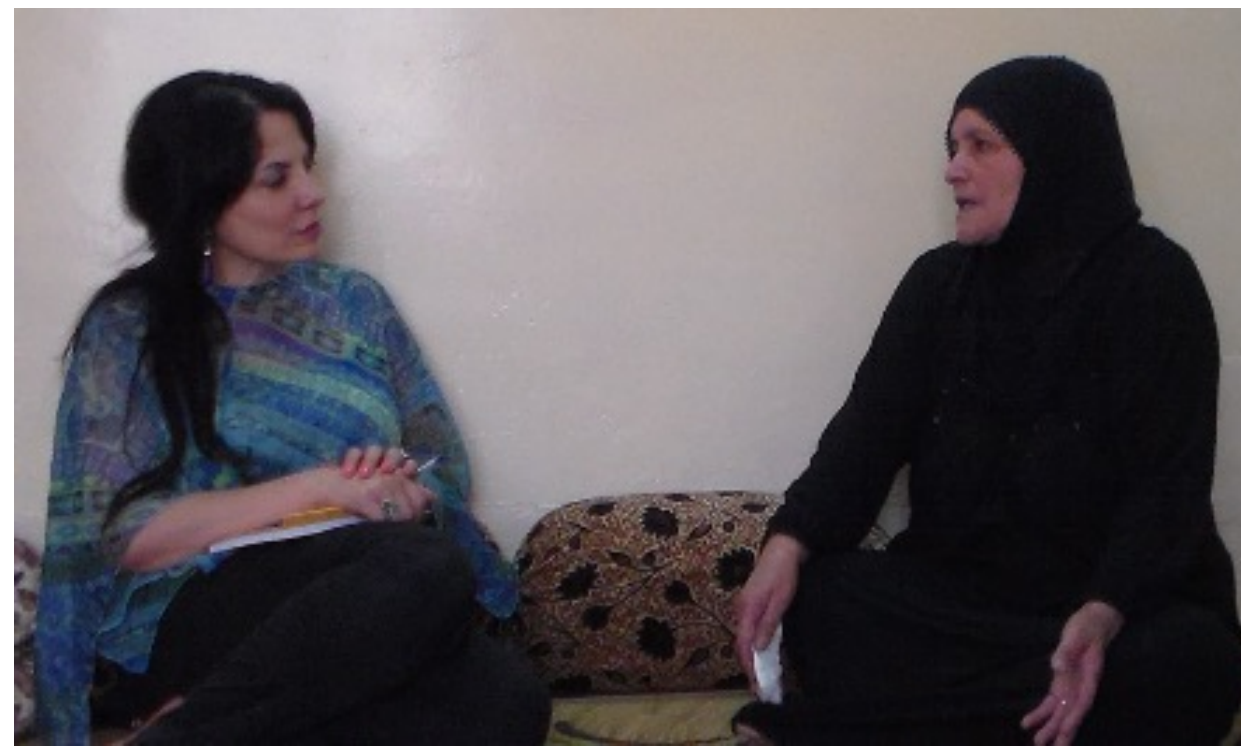

Image 1. Kaziwa Salih \& Nabat Fayiaq Rahman, image courtesy of the author.

I looked in Nyan's direction. She seemed engrossed in taking photos. I wish she too had noticed Nabat's reaction to the design on the pillow, and processed it in the same way I did.

It didn't take long for the tomato and cucumber salad to be placed before me. "You have to eat with me," I told Nabat.

"No, I don't eat anything that has cucumber."

“Why? Do you have an allergy?" 
"I wish," she said, and sighed.

I realized then that the salad hadn't been as effortless to make, as I'd thought. I was overcome with guilt.

Nabat has not eaten a cucumber for more than 30 years. Cucumbers remind her of an incident in the concentration camp of Negrosalman, where her five-year-old Sharooh was very sick and had a fever and diarrhea like most of the children and elderly people on the premises. Sharooh, she said, was crying continuously and asking for ice and cucumber. "Imagine that. We couldn't even get water," added Nabat.

Then she grew silent, and tears ran down her cheeks. I gave her the glass of water I was holding. She took gulps of it and continued, "There was a soldier in front of the camp's door. He had a tub of cucumbers in front of him; he and his soldier friends were eating from it. I told him that my child was taking her last breath and asking for a cucumber. That maybe she smelled it because he was eating it close to our door." I urged him to give me one, she added.

"He didn't answer at first. Then I again urged him to help, told him that my child would die soon. Not for me or her, just for God's sake, give me a small cucumber, don't ignore her last desire."

Nabat's sobbing grew louder.

Nobody, I thought, seemed to realize that the origin of all these brutalities lay in the lack of empathy for 'the other,' our estrangement from those we deemed different from who we are. In fact, I was reminded then of one of the golden rules taught to us in conducting research: that we are not expected to get emotionally involved with our interviewees.

Nabat said, "The soldier threw a few cucumbers down in front of himself and started smashing them into the ground with his big combat boots." She looked down and shook her head. "I thought my daughter was going to die, and I had to do something to give her a little hope before she left this world. I found a green slipper and put it in her hand. My child believed it was a cucumber, and started biting into it. After a while, she died." Nabat continued to sob and after a long inhale and exhale, added, "Only 40 days afterward, my son Diary also died after he got sick."

I was deeply moved. What a strong woman, I thought. Without disrupting the mood and flow of our conversation, I told her, "Now I know why, among hundreds, I was drawn to talk to you: because you're a strong woman and a great mother. You are truly an achiever."

"Not anymore," she replied. "I'm overwhelmed with sorrow."

Like many other survivors of the Anfal genocide, Nabat confirmed that they didn't have enough tools to dig graves for the people who died in the camps. They were merely buried under thin layers of soil. Sometimes at night, they heard the wild dogs from the desert uncovering and eating the corpses.

I wanted to ask about her husband, but at that moment she was again staring vacantly outside. Then her gaze moved to a pencil drawing of a young man that was affixed on the wall nearby.

"Is he your son?" I asked. 


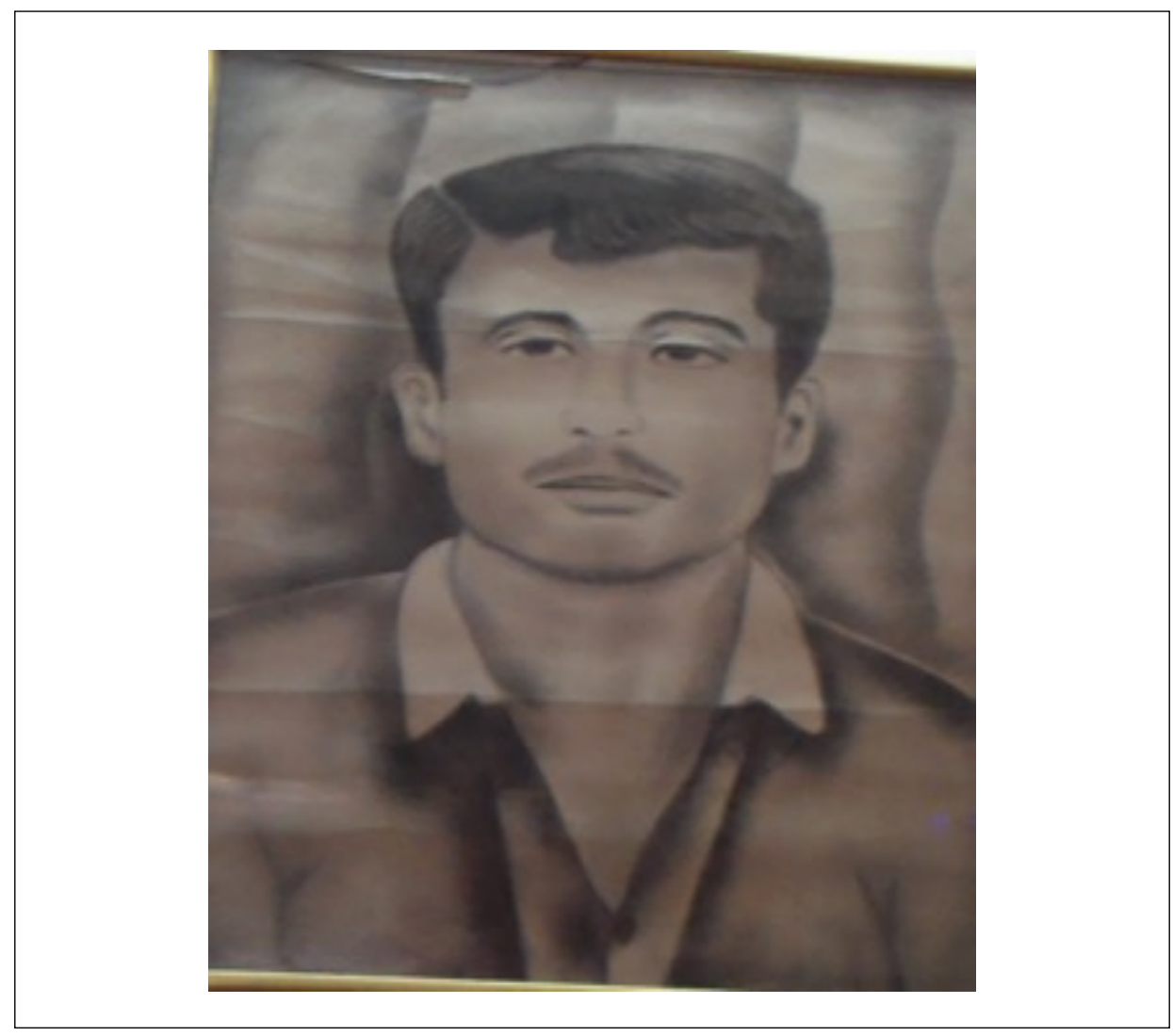

Image 1. Nabat's husband, image courtesy of the author.

"No, it's a picture of my husband."

"How long before the Anfal was that photo taken?"

"Only a few years before the Anfal. This photo was on his eh, ahm... identity." She didn't remember the term "identity card." She added, "A relative redrew it. That is all we have of him."

Obviously, he would have been a young parent like Nabat. He too didn't experience a proper, fulfilling childhood, and he would have died by being buried alive, or after being shot or killed through torture or hunger, and later fed to the Negrosalman wild dogs-Like so many others.

No one would know.

It was known that before destroying their houses, perpetrators would loot the victims' property, including jewellery, livestock, and pets. That was why surviving victims often remained without a history or memories, nor even with something as banal as family photos. If and when they returned, they owned nothing and had nowhere to go. Consequently, the remaining children could not go to school because they lacked the financial means.

"Your husband's history is lost, just like the history of his people," I remarked.

"The history of all of us," Nabat said, "and the real frustration is losing your loved ones; not even having a real photo of them to look at."

I paused for a while, mulling over whether I should tell her about my experiences of the Anfal. 
Finally, I said: "I know what it's like to be without a family history." I felt guilt, remorse, embarrassment. "The Ba'ath imprisoned my father almost every year. Most of the time, my mother would take the children-my siblings and I-to one of the villages so she could protect us from being put in prison. Often when we would be back, belongings from our home would be looted or confiscated. I don't have anything from my childhood. No one in my family has any signs or evidence of our history."

A wound flung on one's memory lasts longer than any other type of wound. Indeed, things do come to an end but memories last forever. I recalled my second year in elementary school: A few classmates decided to share their childhood photos with one another. Some of them were my best friends, and had assumed I'd be part of this activity.

But I didn't have any photos, nor even a doll or a toy to remind me of my childhood.

It may sound simple, but it never is. Not when a child comes to a mother, an older woman, and asks her to prove she was once a child, her child, or suddenly exclaims that she couldn't possible be the woman's child, because if she was, then where are the toys, she emphasises, the childhood photos and other memorabilia?

I didn't need to be a scholar to know that rape was a tool of genocide and war. Since I started working on the genocide of the Kurds, I've been interested in questions of sexual violence against victimized women.

I've tried to broach the subject several times, and gain confirmation that the women of the Anfal were indeed rape and sexual assault victims; especially how they dealt with it in the aftermath, but I've always been pushed away by male family members of victims, or by male directors of genocide institutions.

It was important for me I thought, to ask Nabat whether she had witnessed these atrocities in concentration camps. Or maybe it would be wiser to delay asking the question till the end, just in case it affected her mood.

Questioning the victim, I've long concluded, isn't half as difficult as thinking about Kurdish scholars' and feminists' positions regarding victimized women. It's disappointing that Kurdish scholars have written books on Kurdish women who've been victims of the Anfal genocide, especially in gender studies, but they've never asked questions about rape, explaining why victims have never been able to seek counselling.

Nabat didn't like my question. It made her uncomfortable. She looked to her right, and her upper-right lip twitched twice. Then, reluctantly, she said, "I don't know. In the concentration camps, we never talked about it. But sometimes, the soldiers would take the ladies who were young and beautiful and return them a few hours later. They were sad and withered day by day. We didn't ask them-we all had enough on our plates-but we also knew that those women were raped."

It was the same answer that my aunt Rabia, my mother's sister, gave me years ago. She was released after almost two years because she was elderly. I also heard the same story from another relative who was from Garmin.

The similarity of these accounts was undeniable, and clearly, it was a confirmation of what I'd thought all along. 
The cultural practice of wearing black to mourn the death of a loved one, has always tormented me. In my book Feminism and Kurdish Society (2005), I explored the psychological consequences of this dark culture. However, writing for the undereducated traumatized class of society is worthless if activist groups don't transmit and convert academic or theoretical ideas into a practical, digestible form through counselling and hands-on workshops.

I asked Nabat: "Do you know the black outfit you wear, creates more of a psychological burden?"

"What can I say. Inside, everything is black for me. I can't wear colours. No one does. All the Anfal survivors are still wearing black".

I knew this would lead to nowhere.

Despite everything, Nabat managed to raise her five children to be healthy and strong. She is now one of the bold voices of the survivors. To tell her story, she participates in local, national, and international conferences "I've been to Europe a few times for conferences. Despite all the difficulties I'm going through, I don't mind going wherever I can to defend the rights of the victims. Unfortunately, we [the Kurds] don't respect anything," Nabat said, shaking her head. Suddenly, her lips locked tightly, as if she regretted what she had said. I knew what she meant: no one understands each other better than people with similar experiences.

She mentioned that instead of attracting help and encouragement, she has sometimes been accused of making money out of her horrifying experience. "But I don't pay attention to people without empathy.

"I congratulate you on your determination. Ignore what they're saying, and don't look back, go forward." I replied.

For the first time, a smile lit up her face. I asked her about what she wanted to achieve and where she wished to be heard.

Nabat said, "If the international community knew about our stories and our current conditions, they wouldn't accept it. They would punish the Iraqi government and the Kurdish individuals who don't care about our victimization. In essence, Nabat was asking the international community to create an agency that could stop this kind of crime, hoping no one else would experience what she had gone through; that her voice could help guarantee a safer future for her children. "If we, as victims, don't tell our stories, who is going to make our voice heard?"

I didn't want to disappoint her further by revealing what I knew to be the true face of the international community.

For the first time, I was happy that Nabat Fayiaq Rahman was illiterate, and couldn't read these words. If she'd asked me in 2017 where I would publish her story, what should I have said? Could I tell her the truth?

For instance:

- Nabat, for three years, the mainstream Canadian media have rejected publishing 700 words of your story, with the excuse that it's not current and not related to Canadian society. 
Rejection of your story, Nabat, indicates that even if members of your community hold Canadian passports, they are not considered Canadians; in fact the pain of their genocide is irrelevant to Canadian society.

- Nabat, I have contacted several feminist media outlets, and they called your story dark and heavy on the readers' hearts; they don't want to lose readers because of your story. One of them even asked me to write a weekly column, on one condition: to not tell your kind of story, but the kinds of stories that can turn women's issues into a lucrative business that would enable them to use them on products and have a store on Amazon.

- Nabat, no problems occur in the world without the permission of the international community. They knew your story before it happened.

- Or should I just tell her the international community against genocide consists only of a few organizations and a number of genocide studies scholars? That even these scholars can't magnify her voice if her people and government won't come forward-something that has not happened in at least the last three decades.

Just like your people, Nabat, your voice is without a homeland. Carry on singing your sorrowful lullaby, for it is the only true weapon; the only true balm you have before you lose your voice. 